\title{
Linkages between extracellular enzyme activities and the carbon and nitrogen content of grassland soils
}

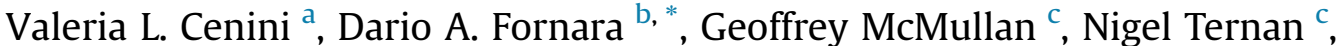 \\ Rachael Carolan ${ }^{\text {b }}$, Michael J. Crawley ${ }^{\mathrm{d}}$, Jean-Christophe Clément ${ }^{\mathrm{e}}$, Sandra Lavorel ${ }^{\mathrm{e}}$ \\ a Environmental Sciences Research Institute, Ulster University, Coleraine BT52 1SA, UK \\ ${ }^{\mathrm{b}}$ Agri-Food \& Biosciences Institute, BT9 5PX Belfast, UK

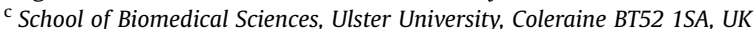 \\ d Department of Life Sciences, Imperial College, Silwood Park, Ascot, Berkshire SL5 7PY, UK \\ e Laboratoire d'Ecologie Alpine, UMR CNRS 5553, Université Grenoble Alpes BP53, 38041 Grenoble Cedex 9, France
}

\section{A R T I C L E I N F O}

\section{Article history:}

Received 27 October 2015

Received in revised form

16 February 2016

Accepted 19 February 2016

Available online 3 March 2016

\section{Keywords:}

Land use

Nutrient fertilization

Lime

$\mathrm{pH}$

$\beta$-1,4-Glucosidase

Extracellular enzymes

\begin{abstract}
A B S T R A C T
Important biochemical reactions in soils are catalyzed by extracellular enzymes, which are synthesized by microbes and plant roots. Although enzyme activities can significantly affect the decomposition of soil organic matter and thus influence the storage and cycling of carbon (C) and nitrogen (N), it is not clear how enzyme activities relate to changes in the $\mathrm{C}$ and $\mathrm{N}$ content of different grassland soils. Here we address whether the activity of $\mathrm{C}$-acquiring ( $\beta$-1,4-glucosidase, $\mathrm{BG}$ ) and $\mathrm{N}$-acquiring (L-leucine aminopeptidase (LAP) and $\beta-1,4-\mathrm{N}$-acetyl-glucosaminidase (NAG)) enzymes is linked to changes in the $\mathrm{C}$ and $\mathrm{N}$ content of a variety of human-managed grassland soils. We selected soils which have a well-documented management history going back at least 19 years in relation to changes in land use (grazing, mowing, ploughing), nutrient fertilization and lime $\left(\mathrm{CaCO}_{3}\right)$ applications. Overall we found a positive relationship between BG activity and soil C content as well as between LAP + NAG activity and soil N. These positive relationships occurred across grasslands with very different soil $\mathrm{pH}$ and management history but not in intensively managed grasslands where increases in soil bulk density (i.e. high soil compaction) negatively affected enzyme activity. We also found evidence that chronic nutrient fertilization contributed to increases in soil C content and this was associated with a significant increase in BG activity when compared to unfertilized soils. Our study suggests that while the activities of $\mathrm{C}$ - and $\mathrm{N}$-acquiring soil enzymes are positively related to soil $\mathrm{C}$ and $\mathrm{N}$ content, these activities respond significantly to changes in management (i.e. soil compaction and nutrient fertilization). In particular, the link between BG activity and the $\mathrm{C}$ content of long-term fertilized soils deserves further investigation if we wish to improve our understanding of the $C$ sequestration potential of human-managed grassland soils.
\end{abstract}

(ङ) 2016 Elsevier Ltd. All rights reserved.

\section{Introduction}

Soil ecosystems represent the largest terrestrial reservoirs of carbon $(\mathrm{C})$ and nitrogen $(\mathrm{N})$ and could act either as sources or sinks of $\mathrm{C}$ and $\mathrm{N}$ depending on the net effect of multiple environmental factors including soil management by humans (Post and Kwon, 2000; Lal, 2004). Changes in the storage and cycling of $\mathrm{C}$ and $\mathrm{N}$ are strongly dependent on the rate of decomposition of organic detritus returned to soils and the incorporation of $\mathrm{C}$ and $\mathrm{N}$ into stable soil

\footnotetext{
* Corresponding author. Tel.: +44 (0)28 90255335.

E-mail address: dario.fornara@afbini.gov.uk (D.A. Fornara).
}

organo-mineral fractions. Soil organic matter (SOM) decomposition is a predominantly microbial-mediated process whereby soil microorganisms produce a variety of extracellular enzymes, which serve a dual function: (1) to catalyze a set of chemical reactions involved in the degradation of SOM, and (2) to acquire the necessary energy and nutrient resources for the enzyme producers (Sinsabaugh et al., 2009; Brzostek and Finzi, 2011; Wallenstein et al., 2011). Enzyme activities in soils represent key biological processes that link the quality of SOM (e.g. the relative availability of $\mathrm{C}$ and $\mathrm{N}$ ) with the ability of microbes to assimilate nutrients and use $C$ for their own metabolism (Allison et al., 2011). This suggests that shifts in $\mathrm{C}$ - or $\mathrm{N}$-acquiring enzyme activities may be linked to changes in the availability and/or storage of $\mathrm{C}$ and $\mathrm{N}$ within SOM pools. 
Recent studies show that soil enzyme activity is associated with changes in SOM concentration across different terrestrial ecosystems (Sinsabaugh et al., 2008; Trasar-Cepeda et al., 2008; Stursová and Baldrian, 2011; Wallenius et al., 2011). Despite this evidence, our mechanistic understanding of whether shifts in the activity of $\mathrm{C}$ - or $\mathrm{N}$-acquiring enzymes might be linked to changes in soil $\mathrm{C}$ and $\mathrm{N}$ content is still limited. Greater SOM accumulation can lead to increases in the activity of extracellular enzymes 'simply' by providing a wider range of $\mathrm{C}$ and $\mathrm{N}$ substrates that can be accessed and utilized by a variety of soil microbial groups. In addition, increased stratification of SOM can lead to higher spatial heterogeneity of the soil matrix, which in turn can be associated with a larger number of niches available to microbial enzyme foraging (Allison, 2005).

Changes in microbial enzyme activities in response to land management practices may themselves actively influence SOM concentration and thus soil $\mathrm{C}$ and $\mathrm{N}$ content. For example, the stimulation or repression of $\mathrm{C}$ - or $\mathrm{N}$-acquiring enzymes could influence rates of SOM decomposition (Burns et al., 2013). Furthermore, once released into the soil, these extracellular enzymes may accumulate, adsorb and stabilize onto mineral surfaces thus contributing to increases in the $\mathrm{C}$ and $\mathrm{N}$ content of SOM (Kandeler et al., 1999; Cotrufo et al., 2013). When enzymes are sorbed to mineral surfaces they become less effective in degrading $\mathrm{C}$ and $\mathrm{N}$ compounds thus contributing to greater $\mathrm{C}$ and $\mathrm{N}$ accumulation in mineral soil pools (Allison and Jastrow, 2006; Grandy et al., 2008).

The main goal of our study is to address whether and how changes in soil $\mathrm{C}$ and $\mathrm{N}$ content correlate significantly with changes in the activity of $\mathrm{C}$ - and $\mathrm{N}$-acquiring enzymes in grasslands characterized by very different human management histories. Based on previous studies (Sinsabaugh et al., 2008; Trasar-Cepeda et al., 2008; Stursová and Baldrian, 2011; Wallenius et al., 2011), we hypothesize that soil $\mathrm{C}$ and $\mathrm{N}$ content should be positively related to the activity of $\mathrm{C}$-acquiring and $\mathrm{N}$-acquiring enzymes in most grassland soils. In particular we hypothesize the existence of a positive feedback between soil $\mathrm{C}$ ( or $\mathrm{N}$ ) content and the activity of the $\mathrm{C}$-acquiring (or $\mathrm{N}$-acquiring) enzyme. Because we included in our analyses soil types characterized by very different $\mathrm{pH}$ values and because soil $\mathrm{pH}$ can strongly influence both enzyme activity (Turner, 2010) as well as soil C and N (Fornara et al., 2011) we also ask whether enzyme activities might relate to changes in $\mathrm{C}$ and $\mathrm{N}$ content across soils with different $\mathrm{pH}$ values.

Secondly, we ask whether and how past and current management practices (i.e. management history) have influenced the relationship between enzyme activity and soil $\mathrm{C}$ and $\mathrm{N}$ content. Here we compare two sets of grasslands, one of which has been historically managed as permanent grassland and the other, which had been regularly ploughed until the 1960s. We also compare permanent grasslands, which are distributed along a gradient of use intensity (i.e. management intensity) as determined by livestock density, nutrient fertilizer and liming applications (i.e. $\left.\mathrm{CaCO}_{3}\right)$.

Finally, we compare grasslands, which have received long-term applications of $\mathrm{N}$ (i.e. nutrient fertilization), asking how the increased availability of $\mathrm{N}$ relative to $\mathrm{C}$ has ultimately influenced the activity of $\mathrm{C}$ - and $\mathrm{N}$-acquiring enzymes as well as the relationship between enzyme activities and the $\mathrm{C}$ and $\mathrm{N}$ content of these grassland soils.

\section{Methods}

We selected grassland soils, which had a clear history of human management and are established across three European regions. Our aim was to select soils that have been undergoing specific treatments (e.g. nutrient fertilization, grazing, liming) for $\geq 19$ years, as follows.

\subsection{Nash's field (England)}

Nash's Field is a long-term grassland experiment that was set up in 1991 at Silwood Park, Berkshire, England. This area is characterized by a temperate oceanic climate with average annual temperature of $9.6^{\circ} \mathrm{C}$ and annual precipitation of $754 \mathrm{~mm}$ (www.clima tedata.eu). Nash's Field is a species-poor grassland lying on acid, sandy soil. The experiment is a split-plot design, which includes large (randomly distributed) blocks (each $900 \mathrm{~m}^{2}$ ) within which are nested multiple experimental treatments (see Edwards and Crawley, 1999). In our study we specifically tested for the effects of (1) rabbit grazing ( \pm rabbit fencing), (2) liming ( \pm lime, i.e. $\mathrm{CaCO}_{3}$ ), and (3) nutrient treatments $( \pm \mathrm{N}, \mathrm{P}, \mathrm{K}$ and $\mathrm{Mg}$ fertilizers nutrients) on enzyme activities and soil $\mathrm{C}$ and $\mathrm{N}$ content. Rabbit grazing was excluded by using $1 \mathrm{~m}$ high fences with wire mesh ( $3 \mathrm{~cm}$ diameter mesh size). Each fenced and grazed plot $\left(400 \mathrm{~m}^{2}\right)$ was divided in two equal plots, one of which was randomly selected to receive lime applications ( 5 tons $\mathrm{CaCO}_{3} \mathrm{ha}^{-1}$ ) and the other not. Each of the limed and non-limed plots $\left(144 \mathrm{~m}^{2}\right)$ was then split into subplots $\left(4 \mathrm{~m}^{2}\right)$ for the application of five different nutrient combinations (N-only, P-only, N and P together, all nutrients-N, P, K and $\mathrm{Mg}$ ) plus a control plot without any nutrient treatment. Mineral nutrients have been applied yearly with the following concentrations: $100 \mathrm{~kg} \mathrm{ha}^{-1}$ of $\mathrm{N}$ (as ammonium nitrate- $\mathrm{NH}_{4} \mathrm{NO}_{3}$ ), $35 \mathrm{~kg} \mathrm{ha}^{-1}$ of $\mathrm{P}$ (as triple superphosphate), $225 \mathrm{~kg} \mathrm{ha}^{-1}$ of $\mathrm{K}$ (as muriate of potash) and $11 \mathrm{~kg} \mathrm{ha}^{-1}$ of $\mathrm{Mg}$ (as Epsom salts). Total atmospheric N deposition is estimated as $\sim 22 \mathrm{~kg} \mathrm{~N} \mathrm{ha}{ }^{-1} \mathrm{y}^{-1}$ (www.apis.ac.uk). In summary, the experiment has 4 large blocks (each $900 \mathrm{~m}^{2}$ ), 8 rabbit grazing plots (each $400 \mathrm{~m}^{2}$ ), 16 liming plots (each $144 \mathrm{~m}^{2}$ ), and a total of 80 nutrient plots (each $4 \mathrm{~m}^{2}$ ), which were sampled in 2011 . Four soil cores ( $3 \mathrm{~cm}$ diameter) were collected from each nutrient plot between 0 and $20 \mathrm{~cm}$ soil depth.

\subsection{Lautaret (France)}

The Lautaret experimental site is located in the Central French Alps on the south-facing slope of the upper valley of the Romanche River (Villar d'Arène, $45^{\circ} 03^{\prime} \mathrm{N}, 6^{\circ} 24^{\prime} \mathrm{E}$ ). Winters are cold and snowy (mean February temperature of $-7.4^{\circ} \mathrm{C}$ ), summers are cool (mean July temperature of $13^{\circ} \mathrm{C}$ ), while average annual precipitation is 956 mm (see Lavorel et al., 2007, 2011 and Robson et al., 2007 and for more details). The total area is $13 \mathrm{Km}^{2}$ and the elevation ranges between 1552 and $2500 \mathrm{~m}$ a.s.l. Historical land use trajectories, representing combinations of past and present land use were defined based on historical records and aerial photography (Quétier et al., 2007). Former arable fields (1650-2000 m) were converted to grasslands fifty years ago and are currently used for hay or grazing by sheep or cattle; former (never ploughed) hay meadows (1800-2000 m) are either still mown or grazed by sheep; summer grasslands ( $>2000 \mathrm{~m}$ ) have remained under pastoral use over history. In this study we investigated 5 trajectories: three representing previously (until the 1960s) cultivated terraces (1) currently fertilized (mainly animal manure) and mown, (2) mown, (3) unmown and grazed in spring and autumn, and two representing never cultivated (never ploughed) permanent grasslands with a multi-century history of mowing (4) currently mown, and (5) unmown (for $>30$ years) and summer grazed. Applications of organic nutrient manure generally occur between May and June each year and on average correspond to the addition of $8 \mathrm{~kg} \mathrm{~N} \mathrm{ha}^{-1} \mathrm{yr}^{-1}$ (Robson et al., 2007). Here we randomly sampled 2 large grassland replicate plots under each of the five land use trajectories. The plots measured $15 \times 15 \mathrm{~m}$ and within each we 
collected 10 random soil samples between 0 and $20 \mathrm{~cm}$ soil depth.

\subsection{Agricultural grasslands (Northern Ireland)}

We selected 45 permanent grasslands dominated by Lolium perenne L. (perennial ryegrass) at three lowland farm sites in County Antrim $\left(54^{\circ} 45^{\prime} \mathrm{N}, 5^{\circ} 55^{\prime} \mathrm{W} ; 54^{\circ} 41^{\prime} \mathrm{N}, 6^{\circ} 12^{\prime} \mathrm{W}\right)$ and County Fermanagh $\left(54^{\circ} 22^{\prime} \mathrm{N}, 7^{\circ} 43^{\prime} \mathrm{W}\right)$, Northern Ireland. The regional climate is temperate and relatively humid influenced by the North Atlantic Drift with mean annual average temperatures and precipitation of $10^{\circ} \mathrm{C}$ and $900 \mathrm{~mm}$ at the Antrim sites and $8.5^{\circ} \mathrm{C}$ and $1300 \mathrm{~mm}$ at the Fermanagh site respectively (Sweeney, 1997). These grasslands are grazed on a rotational basis by cattle, fertilized and cut for silage three times a year. The three farms were selected because of their detailed management history, which dates back at least 20 years. We selected the three farms along a gradient of land use intensity based on the density of livestock (cattle) units (i.e. stocking rate) and the application of nutrient fertilizers (N, P, K) and lime $\left(\mathrm{CaCO}_{3}\right)$. Farm 1 is less intensively used having stocking rates of 0.8 animals ha ${ }^{-1}, 163 \mathrm{~kg} \mathrm{~N}, \mathrm{P}, \mathrm{K} \mathrm{ha}^{-1} \mathrm{yr}^{-1}$ and $52 \mathrm{~kg}$ lime $\mathrm{ha}^{-1} \mathrm{yr}^{-1}$; Farm 2 is more intensively used having rates of 1.2 animals ha ${ }^{-1}, 130 \mathrm{~kg} \mathrm{~N}^{\mathrm{P}}, \mathrm{K} \mathrm{ha}^{-1} \mathrm{yr}^{-1}$ and $97 \mathrm{~kg}$ lime ha ${ }^{-1} \mathrm{yr}^{-1}$; Farm 3 is the most intensively used having rates of 2.05 animals ha ${ }^{-1}, 209 \mathrm{~kg} \mathrm{~N}, \mathrm{P}, \mathrm{K} \mathrm{ha} \mathrm{hr}^{-1}$ and $281 \mathrm{~kg}$ lime $\mathrm{ha}^{-1} \mathrm{yr}^{-1}$. Synthetic nutrient fertilizer has a macronutrient NPK ratio of $20-10-10$ (i.e. $20 \% \mathrm{~N}, 10 \% \mathrm{P}_{2} \mathrm{O}_{5}, 10 \% \mathrm{~K}_{2} \mathrm{O}$ ). Ten soil cores ( $3 \mathrm{~cm}$ diameter) were collected from each grassland between 0 and $20 \mathrm{~cm}$ soil depth.

\subsection{Soil sampling and analyses}

Across all our selected grasslands we collected soil samples using a 3 -cm diameter $\times 20$-cm deep soil corer. Fresh soil samples were passed through a $2-\mathrm{mm}$ sieve by hand prior to subsampling and laboratory analysis. Total soil $\mathrm{C}$ and $\mathrm{N}$ was determined by drying fresh soil samples at $40{ }^{\circ} \mathrm{C}$ for 5 days, grinding with a ball mill (Retsch MM 200) and analyzing subsamples by combustion and gas chromatography on a COSTECH Analytical ECS 4010 element analyzer (Costech Analytical, Valencia, California, USA). To assess soil bulk density (BD), two further subsamples were collected using a 8-cm diameter $\times 20$-cm deep PVC soil corer; BD was then calculated as the ratio between the mass of oven-dried soil and volume of fresh soil $\left(\mathrm{g} / \mathrm{cm}^{3}\right)$. Soil $\mathrm{pH}$ was measured using a suspension made of $10 \mathrm{~g}$ of air-dried sieved soil in $50 \mathrm{~mL}$ of deionized (DI) water (1:5 sample to DI water ratio). For the determination of the soil moisture content (\%), a further $10 \mathrm{~g}$ of fresh soil was weighed, dried at $105{ }^{\circ} \mathrm{C}$ to a constant mass (minimum $48 \mathrm{~h}$ ) and reweighed. Two $\mathrm{g}$ of fresh and sieved soil subsamples $(<2 \mathrm{~mm})$ were put into an $8 \mathrm{~mL}$ bijou and then frozen to $-20^{\circ} \mathrm{C}$ for 3 weeks before enzyme analysis.

\subsection{Enzyme analysis}

The activity of three extracellular enzymes (Table 1 ) involved in cellulose decomposition ( $\beta-1,4$ glucosidase (BG)), and $\mathrm{N}$ acquisition (L-leucine aminopeptidase (LAP) and $\beta$-1,4-N-acetyl-glucosaminidase (NAG)) were assayed according to a modification of the method described by Saiya-Cork et al. (2002). The extracellular enzymes were measured fluorometrically using a $200 \mu \mathrm{M}$ solution of 4-methylumbelliferone (MUB) or 7-Amino-4-methylcoumarin (AMC) labeled substrates. Three biological buffers (acetate/maleate/bicarbonate) were used depending on the field soil $\mathrm{pH}$ (acidic/ mildly-acidic and neutral/basic respectively). Using a multichannel pipettor, $50 \mu \mathrm{L}$ aliquots of $50 \mathrm{mM}$ buffer were dispensed in columns of a 96-well black microplates (Nunk ${ }^{\circledR}$ FluoroNunc ${ }^{\mathrm{TM}}$ P8741
Sigma-Aldrich) that served as the blank (buffer + slurry); $200 \mu \mathrm{L}$ aliquots of $50 \mathrm{mM}$ buffer were dispensed in the reference standard (buffer + standard) and negative control (buffer + substrate) columns (8 analytical replicate per soil per assay each). Two grams of previously defrosted soil were homogenized for $4 \mathrm{~min}$ with a Silverston L4R homogenizer (Silverstone Machines Ltd., England) in $250 \mathrm{~mL}$ of $50 \mathrm{mM}$ buffer. The soil suspension (soil slurry) was continuously stirred while $200 \mu \mathrm{L}$ aliquots were dispensed into microplate columns that served as the sample assay (16 analytical replicate soil suspensions for each sample per assay), blank and quench standard (slurry + standard) (8 analytical replicate each). A $50 \mu \mathrm{l}$ aliquot of fluorescence standard solution $(10 \mu \mathrm{M} 4$ methylumbelliferone-MUB-, or 7-amino-4-methylcoumarin-AMCin the case of the LAP assay) was dispensed into microplate columns that served as a reference standard (buffer + standard) and as a quench standard. Finally, sample assay (slurry + substrate) and negative control (buffer + substrate) also received $50 \mu \mathrm{l}$ of a $200 \mu \mathrm{M}$ substrate solution (see Table 1) in a final reaction volume of $250 \mu \mathrm{L}$. Prepared plates were incubated in the dark at $20^{\circ} \mathrm{C}$ for up to $24 \mathrm{~h}$ following substrate addition. Fluorescence was measured without addition of $\mathrm{NaOH}$ (German et al., 2011; Shaw and DeForest, 2013) using a FLUOstar Omega microplate reader (BMG Labtech) with $\lambda 365 \mathrm{~nm}$ excitation and $\lambda 460 \mathrm{~nm}$ emission filters. Following correction of the assay wells' fluorescence measurements for negative controls, blanks and quench standard wells, enzyme activity was expressed as nanomoles of substrate released per hour per gram of dry soil $\left(\mathrm{nmol} \mathrm{h} \mathrm{h}^{-1} \mathrm{~g}^{-1}\right)$.

\section{Data analysis}

Our three grassland sites are located across different geographical areas and under different environmental conditions. Thus we first performed Residual Maximum Likelihood (REML) estimation analyses (which included grassland site as random effect) to test how soil $\mathrm{C}$ and $\mathrm{N}$ content would vary as a function of fixed key environmental variables (i.e. soil pH, BG and NAG + LAP activities). Second, we performed linear regression analyses to address potential relationships between enzyme activities and the $\mathrm{C}$ and $\mathrm{N}$ content of our grassland soils. Third, multiple regression analyses were performed within each dataset to search for potential relationships between enzyme activity and other key environmental factors (e.g. soil pH, livestock density, soil C and $\mathrm{N}$ content etc.). Finally, we performed site-specific analyses using separate mixed effects ANOVAs, which in turn included as random effects either the four large blocks (in the Nash's Field), or the five land use trajectories (at the Lautaret) or the three farmland sites (in Northern Ireland) and as fixed effects the various treatments applied at each site (e.g. grazing, liming, nutrient fertilization etc.). We tested these fixed effects on multiple response variables (i.e. soil $\mathrm{C}$, soil $\mathrm{N}$, soil $\mathrm{pH}$, and extracellular enzyme activities). We used restricted maximum likelihood (REML) methods to produce final models and checked that these models conformed to modeling assumptions. Significant differences between factor levels (i.e. five nutrient treatments in Nash's Field) were tested using post-hoc Tukey tests. Soil and enzyme data were square-root transformed to improve the normality of errors and homogeneity of variance. We also estimated $\mathrm{C}$ - and $\mathrm{N}$-acquiring enzymes activity per unit of soil $\mathrm{C}$ and soil $\mathrm{N}$ respectively by dividing BG (or NAG + LAP) activity by total soil organic $\mathrm{C}$ (and $\mathrm{N}$ ) content. All analyses were conducted using JMP version 9.0 statistical software (SAS Institute Inc. 2010).

\section{Results}

Overall our REML analyses showed that soil $\mathrm{pH}\left(\mathrm{F}_{1,201}=21\right.$; $\mathrm{P}<0.0001)$ and BG activity $\left(\mathrm{F}_{1,201}=24 ; \mathrm{P}<0.0001\right)$ were 
Table 1

Hydrolytic enzymes (and their substrates) assayed in multiple soil samples collected from three main experimental sites across Europe.

\begin{tabular}{|c|c|c|c|}
\hline Enzymes and their function in soils & Final product & E.C. & Substrate \\
\hline$\beta$-1,4-glucosidase (BG) Hydrolysis of cellulose & Glucose (sugar) & 3.2.1.21 & 4-MUB- $\beta$-D gluco (pyrano)side \\
\hline$\beta-1,4-\mathrm{N}$-acetyl-glucosaminidase (NAG). Hydrolysis of chitin. & $\mathrm{N}$-acetyl- $\beta$-D-glucosamine (sugar) & 3.2.1.14 & 4-MUB-N-acetyl- $\beta$-D glucosaminide \\
\hline $\begin{array}{l}\text { L-Leucine aminopeptidase (LAP). Hydrolysis of amino acid residues } \\
\text { ( } \mathrm{N} \text { - terminus of peptides and proteins) }\end{array}$ & Leucine (other amino-acids) & 3.4.11.1 & L-Leucine-7-amido-4 methylcoumarin \\
\hline
\end{tabular}

E.C. = Enzyme Commission number; 4-MUB = 4-methylumbelliferyl.

significantly related to soil $\mathrm{C}$ after we controlled for grassland site identity. Similarly soil $\mathrm{pH}\left(\mathrm{F}_{1,201}=5.7 ; \mathrm{P}=0.03\right)$ and NAG + LAP activity $\left(\mathrm{F}_{1,201}=35 ; \mathrm{P}<0.0001\right)$ were significantly related to soil $\mathrm{N}$ across our grassland sites. Results from linear regression analyses show significant positive relationships between extracellular enzyme activities and soil $\mathrm{C}$ and $\mathrm{N}$ content (Fig. 1) across our study sites.

\subsection{Enzyme activity and soil $C$ and $N$ content across a wide range of soil $\mathrm{pH}$ values}

The positive relationship between enzyme activity and soil $\mathrm{C}$ and $\mathrm{N}$ content was not affected by changes in soil $\mathrm{pH}$ and remained significant between BG and soil C (Fig. $2 \mathrm{a}-\mathrm{C}$ ) as well as between $\mathrm{NAG}+$ LAP and soil N (Fig. $2 \mathrm{~d}-\mathrm{f}$ ) across our grasslands. This suggests that regardless of variation in soil $\mathrm{pH}$ the activity of $\mathrm{C}$ acquiring and $\mathrm{N}$-acquiring enzymes remains significantly related to changes in soil $\mathrm{C}$ and $\mathrm{N}$ content. In different multiple regression analyses where we included both soil $\mathrm{pH}$ and enzyme activity as predictor variables we found that BG and NAG + LAP activities in the Lautaret grasslands remained significantly related to soil $\mathrm{C}$ and $\mathrm{N}$ content respectively (Table 2 ).

\subsection{Enzyme activity and soil $C$ and $N$ content across grasslands with different histories of soil management}

We compared soil enzyme activities between permanent grasslands (never ploughed) and grasslands that underwent regular cultivation and ploughing until the 1960s in the Central French Alps. We found a positive relationship between BG activity and soil $\mathrm{C}$ content of both permanent and historically ploughed grasslands (Fig. 3a). Grassland soils that were historically ploughed and received nutrient additions have a significantly higher soil $C$ content compared to permanent grassland soils $(\mathrm{P}<0.0001)$. Similarly we found a positive relationship between NAG + LAP activity and soil N content of permanent grasslands but not between NAG + LAP and soil $\mathrm{N}$ of historically ploughed (and nutrient-fertilized) grasslands (Fig. 3b).

\subsection{Enzyme activity and soil $C$ and $N$ content in agricultural grasslands}

We found that soil enzyme activities were neither related to soil $\mathrm{C}$ nor to soil $\mathrm{N}$ content in intensively managed agricultural grasslands (Table 3). In multiple regression analyses where enzyme activities were included with soil bulk density and livestock density (i.e. number of cattle per hectare) we found that only soil bulk density and livestock densities were significantly (negatively) related to soil $\mathrm{C}$ and soil $\mathrm{N}$ (Table 3 ).

\subsection{Enzyme activity and soil $C$ and $N$ content under $N$ fertilization}

We found that the addition of $\mathrm{N}$ fertilizer to soils (Nash's field and Lautaret) had a significant positive effect on BG activity (Fig. 4a) and that long-term $\mathrm{N}$ fertilization was also positively related to soil C content (Fig. 4b). We did not find any significant effect of $\mathrm{N}$ fertilization on NAG + LAP activity (Fig. 5a) but $\mathrm{N}$ fertilization had a positive effect on total soil $\mathrm{N}$ (Fig. $5 \mathrm{~b}$ ). $\mathrm{N}$ fertilization had a positive significant effect on BG activity per unit of soil $\mathrm{C}(\mathrm{P}<0.004)$ (Fig. 6a) and a negative significant effect on NAG + LAP activity per unit of soil N (Fig. 6b). Finally, we found that the activities of C- and Nacquiring enzymes were positively related (Fig. 7) and that these activities were affected by $\mathrm{N}$ fertilization. In particular BG activity relative to NAG + LAP increased with increases in $\mathrm{N}$ fertilization whereas NAG + LAP activity relative to BG increased with decreases in $\mathrm{N}$ fertilization. a)

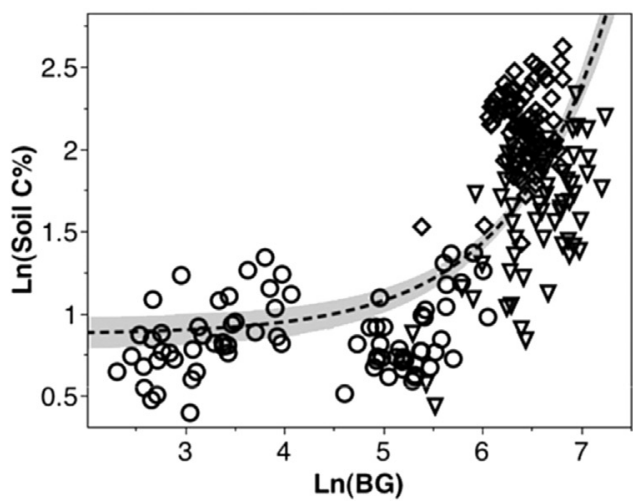

b)

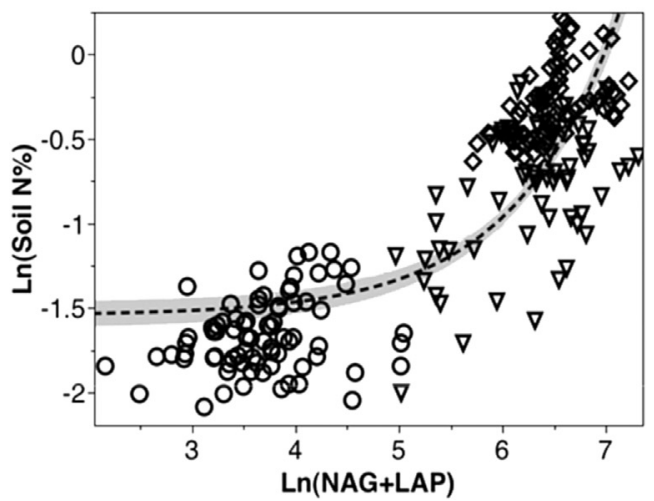

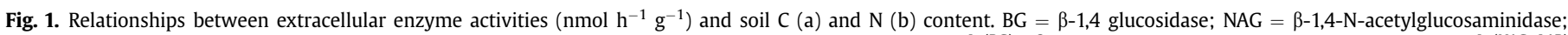

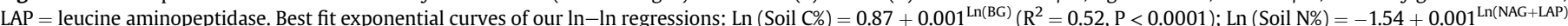

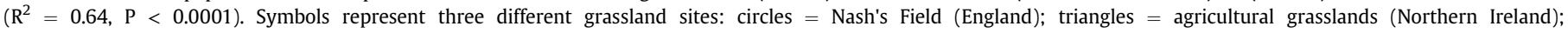
diamonds $=$ Lautaret (France). 
a)

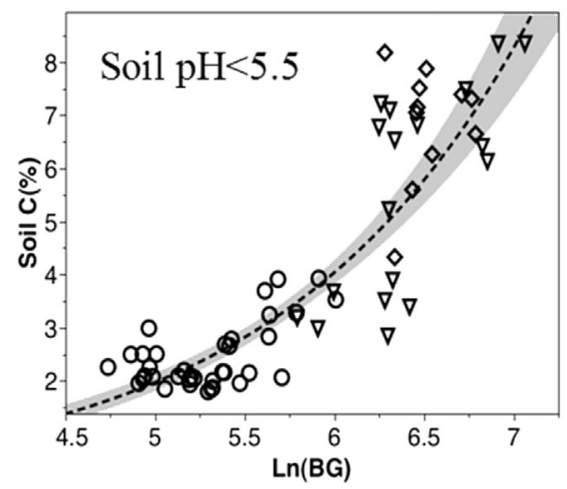

d)

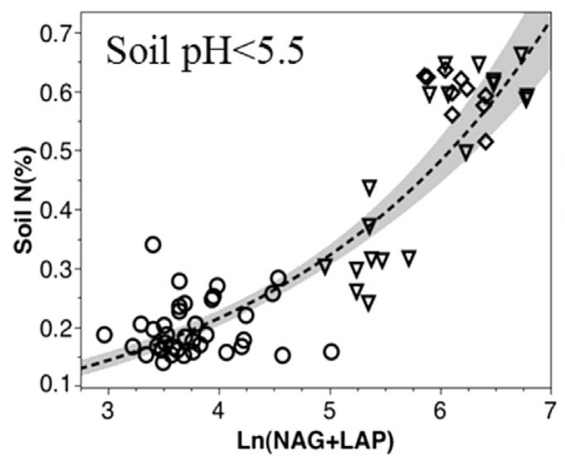

b)

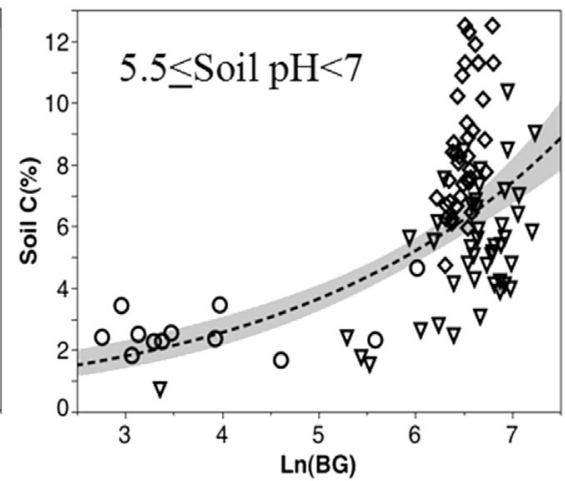

e)

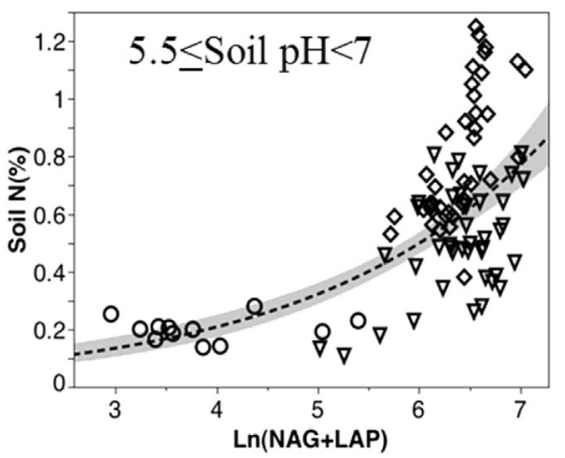

c)

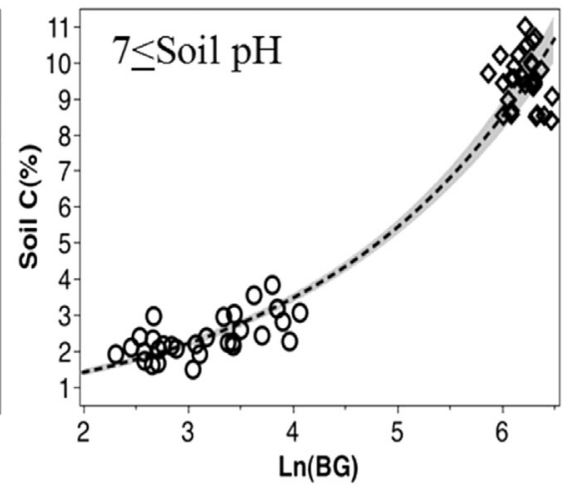

f)

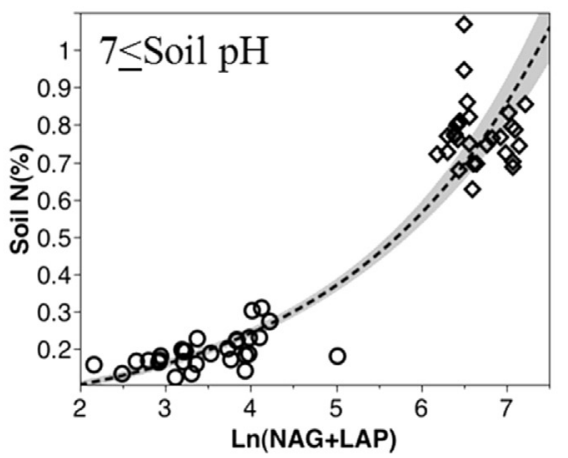

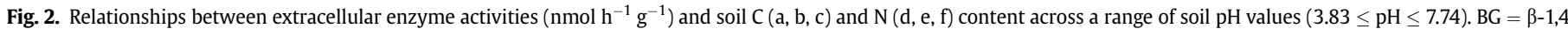

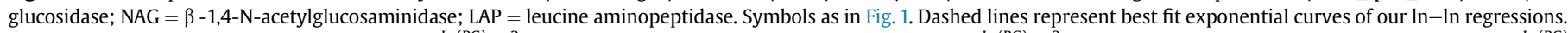

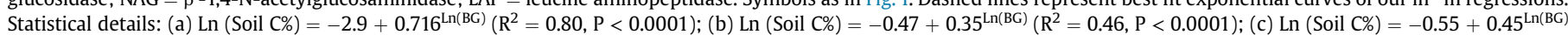

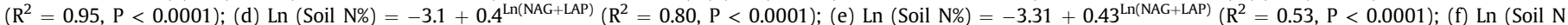
$\%)=-3.1+0.42^{\mathrm{Ln}(\mathrm{NAG}+\mathrm{LAP})}\left(\mathrm{R}^{2}=0.92, \mathrm{P}<0.0001\right)$.

Table 2

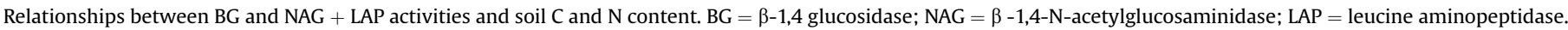
Results are from multiple regression analyses using data from never ploughed and ploughed (until 1960) permanent grasslands in the Central French Alps.

\begin{tabular}{|c|c|c|c|c|c|c|c|}
\hline \multirow[t]{2}{*}{ Independent variables } & \multicolumn{3}{|l|}{ Soil C\% } & \multirow[t]{2}{*}{ Independent variables } & \multicolumn{3}{|l|}{ Soil N\% } \\
\hline & Estimate & t ratio & $\mathrm{P}$ & & Estimate & t ratio & $\mathrm{P}$ \\
\hline Intercept & -15.1 & -12.9 & $<0.0001$ & Intercept & -0.58 & -7.2 & $<0.0001$ \\
\hline Soil pH & 1.6 & 11.8 & $<0.0001$ & Soil pH & 0.03 & 2.9 & 0.004 \\
\hline $\operatorname{Ln}(B G)$ & 1.93 & 18.8 & $<0.0001$ & Ln (NAG + LAP) & 0.15 & 18.8 & $<0.0001$ \\
\hline
\end{tabular}

\section{Discussion}

Overall our results confirm our hypothesis that the activity of both $\mathrm{C}$ - and $\mathrm{N}$-acquiring extracellular enzymes is positively related to the $\mathrm{C}$ and $\mathrm{N}$ content of very different grassland soils. This agrees with the findings from previous studies, which show positive relationships between enzyme activity and soil organic matter (SOM) concentration (Sinsabaugh et al., 2005, 2008). The positive relationship between enzymes activity and soil $\mathrm{C}$ and $\mathrm{N}$ content suggests the existence of direct and/or indirect links between these microbial functions and variation in the $\mathrm{C}$ and $\mathrm{N}$ content of SOM in the grasslands analyzed. It is not clear however, whether it is the greater activity of BG (or NAG + LAP) that ultimately causes increases in soil $C$ (or $N$ ), or whether it is the greater size of the SOM pool which provides more $\mathrm{C}$ and $\mathrm{N}$ substrates that, in turn, ultimately promote greater microbial enzyme activity. To date, there have been few experimental studies that have specifically addressed potential 'cause-and-effect' relationships between enzyme activity and changes in soil $\mathrm{C}$ and $\mathrm{N}$ content (see for example Trasar-Cepeda et al., 2008; Wallenius et al., 2011). It is accepted that soil enzyme activities are closely related to changes in key soil physicochemical properties as well as changes in microbial biomass and SOM content (Caldwell, 2005; Sinsabaugh et al., 2008; Allison et al., 2011; Stursová and Baldrian, 2011).

In our study we demonstrated that increased activity of BG is associated with higher soil $\mathrm{C}$ content and furthermore that this is true across soils with very different $\mathrm{pH}$ values and management histories. In terms of management history our evidence is that BG activity and soil $C$ are positively related either across permanent grasslands or across historically ploughed grasslands. This relationship is particularly significant in ploughed grasslands, which had also received $\mathrm{N}$ additions (Fig. 3a). We are not sure whether increases in BG activity could be related to positive $\mathrm{N}$-induced effects on grass yields (and thus to higher cellulose pools) because 
a)

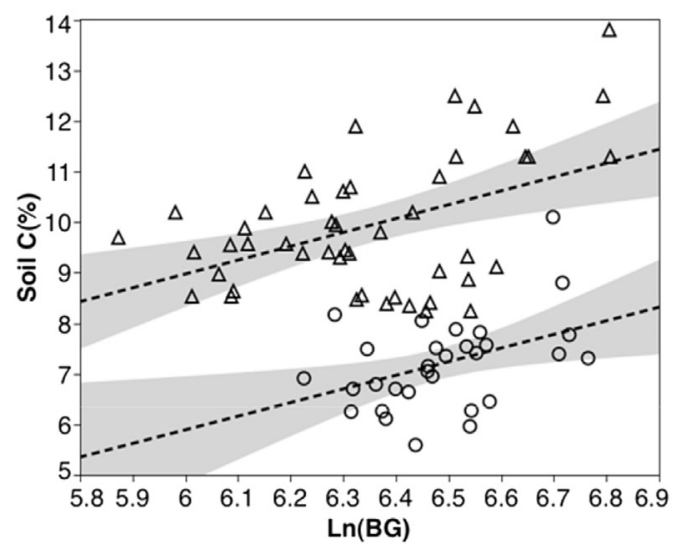

b)

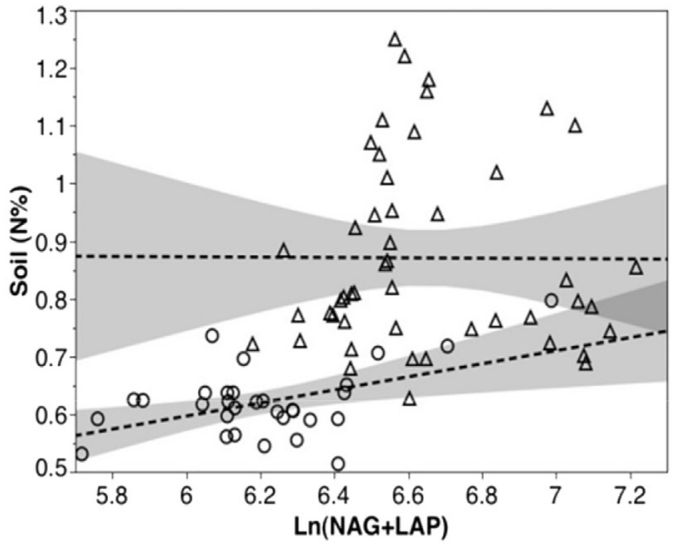

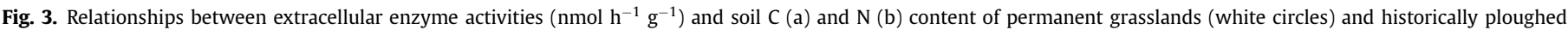

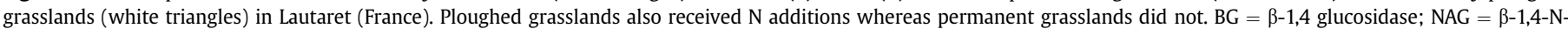

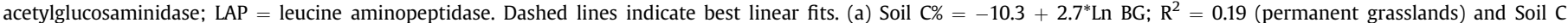

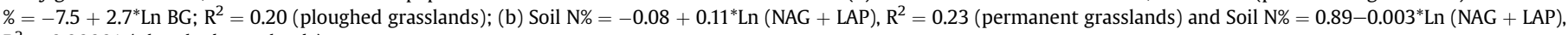
$\mathrm{R}^{2}=0.00001$ (ploughed grasslands).

Table 3

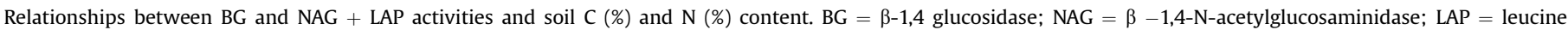

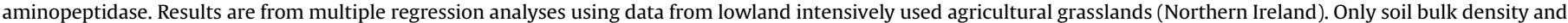
livestock density (i.e. number of cattle per hectare) are significantly (negatively) related to soil C and soil $\mathrm{N}$ content.

\begin{tabular}{|c|c|c|c|c|c|c|c|}
\hline \multirow[t]{2}{*}{ Independent variables } & \multicolumn{3}{|l|}{ Soil C\% } & \multirow[t]{2}{*}{ Independent variables } & \multicolumn{3}{|l|}{ Soil N\% } \\
\hline & Estimate & t ratio & $\mathrm{P}$ & & Estimate & $\mathrm{t}$ ratio & $P$ \\
\hline Intercept & 20 & 4.46 & $<0.0001$ & Intercept & 1.67 & 11.1 & $<0.0001$ \\
\hline Soil Bulk density & -8.7 & -6.7 & $<0.0001$ & Soil Bulk density & -0.67 & -6.5 & $<0.0001$ \\
\hline Livestock density & -1.88 & -5 & $<0.0001$ & Livestock density & -0.16 & -5.8 & $<0.0001$ \\
\hline $\operatorname{Ln}(B G)$ & -0.11 & -0.18 & 0.85 & $\mathrm{Ln}(\mathrm{NAG}+\mathrm{LAP})$ & -0.12 & -1.38 & 0.17 \\
\hline
\end{tabular}

a)

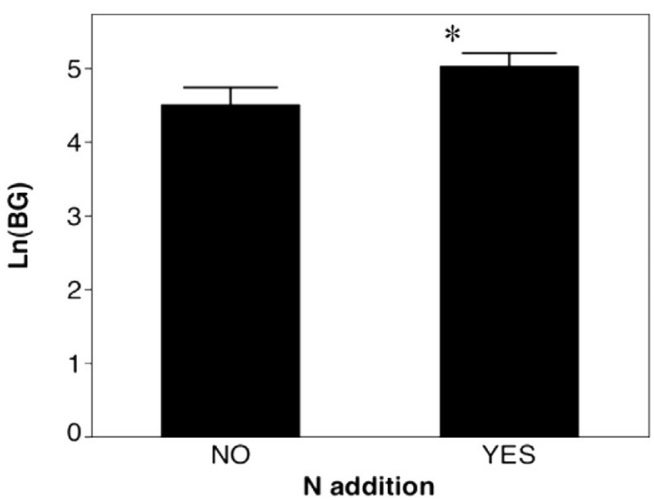

b)

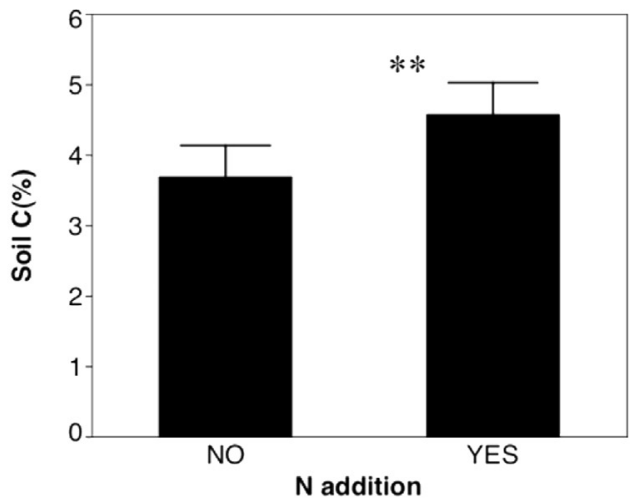

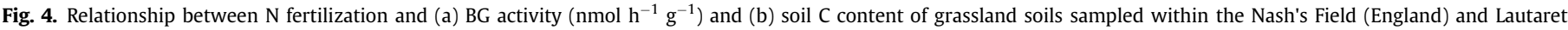
(France) experiments. $\mathrm{BG}=\beta-1,4$ glucosidase ( $\mathrm{ns}=$ not significant, ${ }^{*}<0.01,{ }^{* *}<0.001,{ }^{* * *}<0.0001$ ).

most of aboveground biomass produced every year in these grasslands is removed by humans.

In grassland soils, cellulose represents a significant proportion of plant detritus returned to the soil, and the production of BG is therefore very important for catalysis of the final step in cellulose depolymerization, which is the hydrolysis of cellobiose to glucose (Sinsabaugh and Follstad Shah, 2011). Greater BG activity could be related to plant litter inputs to soils and thus to the pool of cellulose-rich substrates available for decomposition. A recent study shows, for example, how the addition of plant biomass to soils from different cover crops is positively related to both BG activity and soil $C$ sequestration (Peregrina et al., 2014). Once BG has been produced and released into the soil, it could potentially be disabled through binding to mineral and organic colloids (Allison and Jastrow, 2006) thus contributing (together with other microbial 'waste' products) to the accumulation of $\mathrm{C}$ in soils (Cotrufo et al., 2013; Cenini et al., 2015).

Our findings show however that in more intensively managed 
a)

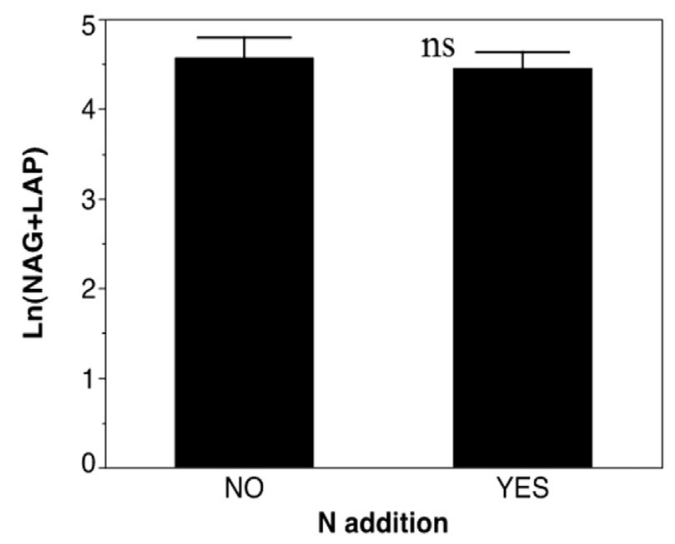

b)

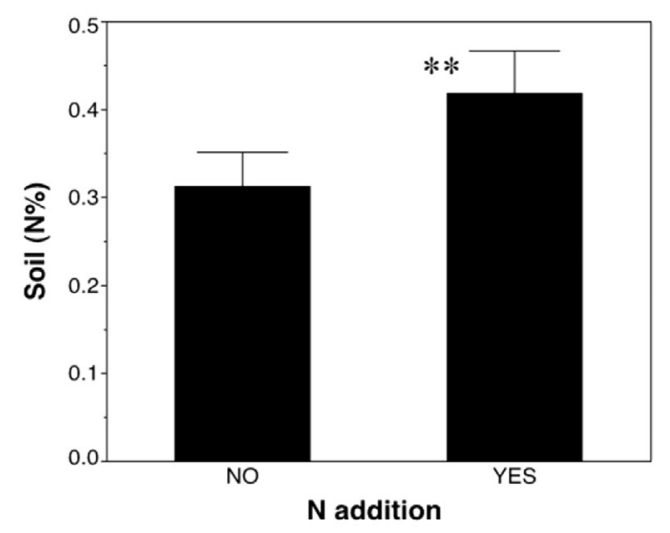

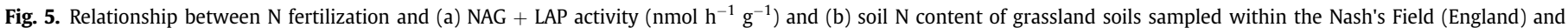
Lautaret (France) experiments. NAG $=\beta-1,4-\mathrm{N}$-acetylglucosaminidase; LAP $=$ leucine aminopeptidase $\left(\mathrm{ns}=\right.$ not significant, ${ }^{*}<0.01$, ${ }^{* *}<0.001$, $\left.{ }^{* * *}<0.0001\right)$.

a)

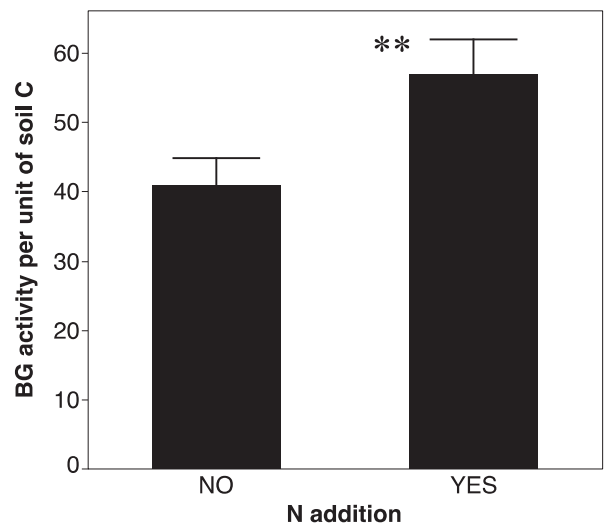

b)

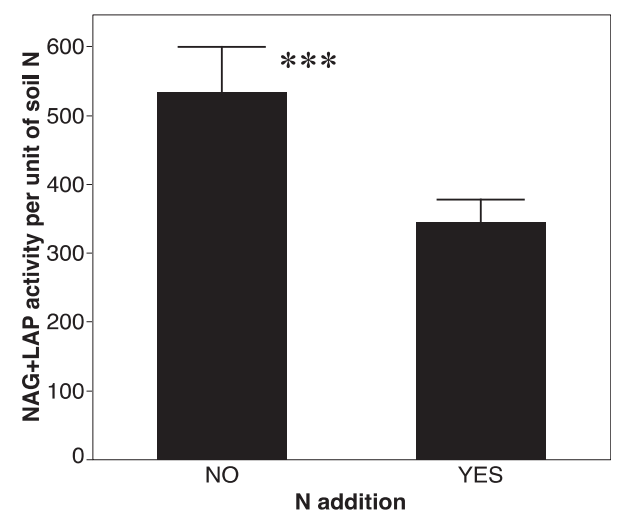

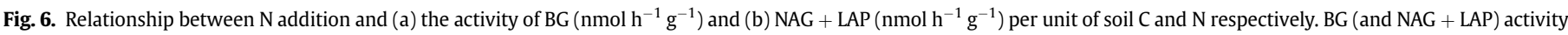

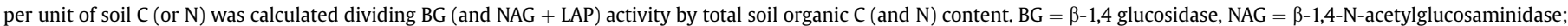
LAP $=$ leucine aminopeptidase. ( $\mathrm{ns}=$ not significant, ${ }^{*}<0.01,{ }^{* *}<0.001,{ }^{* * *}<0.0001$ ).

grasslands (i.e. those with increased livestock numbers and increased soil compaction) the activity of BG and NAG + LAP was not significantly correlated to soil $\mathrm{C}$ and $\mathrm{N}$ content. Enzyme activity and thus the storage of soil organic $\mathrm{C}$ (SOC) is affected by both soil texture and mineral composition and it appears that in the Northern Ireland grasslands we investigated, increases in both soil bulk density and animal stocking rates have significantly negatively affected soil $\mathrm{C}$ and $\mathrm{N}$ content. Previous studies have shown how increased soil compaction can lead to negative effects on microbial activity (Welbaum et al., 2004). Compaction increases soil aggregation, which may prevent enzymes from accessing $\mathrm{C}$ and $\mathrm{N}$ substrates inside aggregates (Sollins et al., 1996).

Our results also show that BG activity responds positively to long-term $\mathrm{N}$ additions to grassland soils (Fig. 4a) and that soils receiving $\mathrm{N}$ additions have significantly greater soil $\mathrm{C}$ content (Fig. 4b). We explain this positive $\mathrm{N}$-induced effect on BG activity based on the fact that the activity of $\mathrm{C}$-acquiring (or $\mathrm{N}$-acquiring enzymes) tends to respond to changes in environmental substrate availability (Chróst, 1991; Sinsabaugh et al., 1993; Allison and Vitousek, 2005). The work of Mergel et al. (1998), for example, showed that $\mathrm{N}$ fertilization stimulated the production of $\mathrm{C}$-containing compounds in soils, compounds which derive from plant root decomposition and from root exudates. Root exudation can also enhance the decomposition of stable forms of organic matter, stimulate mineralization of C-containing compounds and contribute to the incorporation of soil $\mathrm{C}$ forms into stable soil fractions. We expected that long-term $\mathrm{N}$ additions to soils would have contributed a reduced $\mathrm{C} v s$. N availability for microbial growth, thus stimulating the production of $\mathrm{C}$-acquiring rather than $\mathrm{N}$ acquiring enzymes. Our investigation provides evidence of this as fertilized soils showed significantly higher BG activities and lower NAG + LAP activities. This result also agrees with the results of other researchers, which showed that increased inorganic $\mathrm{N}$ availability has negative effects on the activity of $\mathrm{N}$-acquiring enzymes (Stursová et al., 2006). As further support for the positive Ninduced effect on BG, we found that the BG activity per unit of soil C was significantly higher in soils receiving chronic $\mathrm{N}$ additions (Fig. 6a). Nutrient fertilization is a very common practice across human-managed grasslands and its cascading effects on both microbial activity and on soil $\mathrm{C}$ accumulation still need to be clarified.

In our study we did not find any linkages between $\mathrm{N}$ additions, $\mathrm{NAG}+\mathrm{LAP}$ activity and soil $\mathrm{N}$ content. On one side $\mathrm{N}$ fertilization reduced NAG + LAP activity and also the activity of NAG + LAP per unit of soil $\mathrm{N}$. On the other side $\mathrm{N}$ fertilization was positively related 


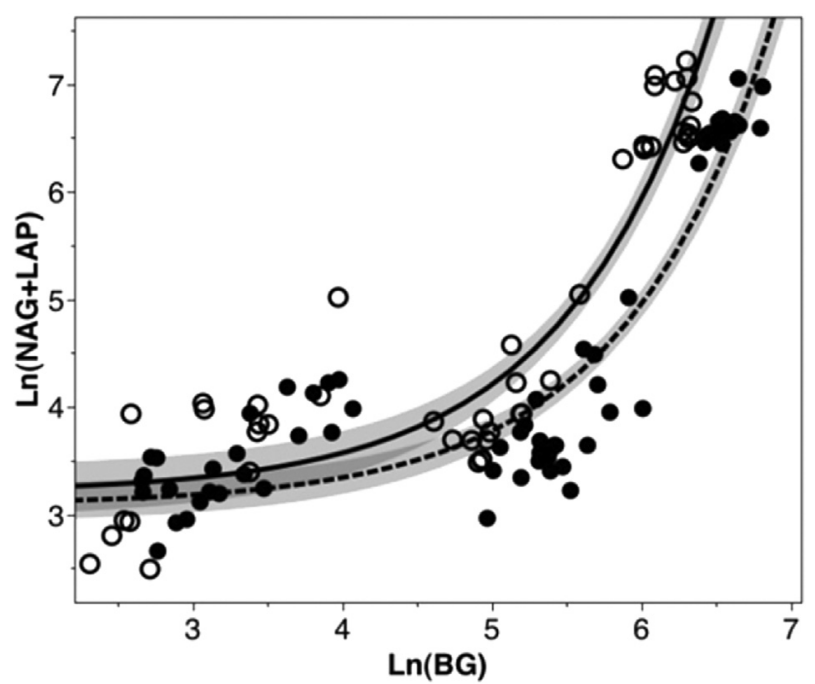

Fig. 7. Relationship between $\ln (\mathrm{BG})\left(\mathrm{nmol} \mathrm{h}^{-1} \mathrm{~g}^{-1}\right)$ and $\ln (\mathrm{NAG}+\mathrm{LAP})\left(\mathrm{nmol} \mathrm{h} \mathrm{h}^{-1} \mathrm{~g}^{-1}\right)$ in soils which have received $\mathrm{N}$ additions (filled circles) and soils which did not receive any $\mathrm{N}$ addition (open circles). $\mathrm{BG}=\beta-1,4$ glucosidase, NAG $=\beta-1,4-\mathrm{N}$-acetylglucosaminidase; LAP = leucine aminopeptidase. Best fit equations: Ln $(\mathrm{NAG}+\mathrm{LAP})=3.2+0.006^{\mathrm{Ln}(\mathrm{BG})}\left(\mathrm{R}^{2}=0.87, \mathrm{P}<0.0001\right.$; white circles $)$ : Ln $(\mathrm{NAG}+\mathrm{LAP})=3.1+0.004^{\mathrm{Ln}(\mathrm{BG})}\left(\mathrm{R}^{2}=0.87, \mathrm{P}<0.0001 ;\right.$ filled circles $)$.

to soil $\mathrm{N}$ content. This apparent mismatch between low activity of $\mathrm{N}$-acquiring enzymes and high soil $\mathrm{N}$ may be simply due to the fact that $\mathrm{N}$ is found in a diversity of compounds (e.g. amino sugars, polypeptides, humus), which are degraded by a diverse range of $\mathrm{N}-$ acquiring enzymes. The addition of inorganic forms of $\mathrm{N}$ to soils through fertilization may as a consequence provide $\mathrm{N}$ forms available to be incorporated in SOM, thus explaining the positive relationship between $\mathrm{N}$ addition and soil $\mathrm{N}$ content (see Fig. 5b).

\section{Conclusion}

Overall, our study shows that the activity of $\mathrm{C}$ - and $\mathrm{N}$-acquiring enzymes is positively related to changes in soil $\mathrm{C}$ and $\mathrm{N}$ content across very different grassland systems. This positive relationship may be explained by the fact that increased accumulation of SOM may provide a variety of $\mathrm{C}$ and $\mathrm{N}$ substrates as well as a range of spatial niches which support greater microbial enzyme foraging and activities. Thus our evidence is that BG activity may represent a good indicator of both soil organic matter quality and $C$ sequestration trends as was found in recent studies (Stott et al., 2010; Cenini et al., 2015). We suggest however, that human-induced changes in grassland management (e.g. $\mathrm{N}$ fertilization, livestock density, soil compaction etc.) significantly influence enzyme activity, which in turn could have consequences for the $\mathrm{C}$ and $\mathrm{N}$ content of SOM. Thus the activity of $\mathrm{C}$ - and $\mathrm{N}$-acquiring enzymes may not be simply a reflection of SOM concentration itself, and that changes in these enzyme activities could actively influence the accumulation of SOM, and also, consequently, the $\mathrm{C}$ and $\mathrm{N}$ content of human-managed grassland soils.

\section{Acknowledgements}

This study was sponsored by a DEL PhD Studentship from Ulster University.

\section{References}

Allison, S.D., 2005. Cheaters, diffusion and nutrients constrain decomposition by microbial enzymes in spatially structured environments. Ecology Letters 8,
$626-635$.

Allison, S.D., Jastrow, J.D., 2006. Activities of extracellular enzymes in physically isolated fractions of restored grassland soils. Soil Biology \& Biochemistry 38, 3245-3256.

Allison, S.D., Vitousek, P.M., 2005. Responses of extracellular enzymes to simple and complex nutrient inputs. Soil Biology \& Biochemistry 37 (5), 937-944.

Allison, S.D., Weintraub, M.N., Gartner, T.B., Waldrop, M.P., 2011. Evolutionaryeconomic principles as regulators of soil enzyme production and ecosystem function. In: Shukla, G., Varma, A. (Eds.), Soil Enzymology, vol. 22. SpringerVerlag, Berlin, Germany, pp. 229-243.

Brzostek, E.R., Finzi, A.C., 2011. Substrate supply, fine roots, and temperature control proteolytic enzyme activity in temperate forest soils. Ecology 92 (4), 892-902.

Burns, R.G., DeForest, J.L., Marxsen, J., Sinsabaugh, R.L., Stromberger, M.E., Wallenstein, M.D., Weintraub, M.N., Zoppini, A., 2013. Soil enzymes in a changing environment: current knowledge and future directions. Soil Biology and Biochemistry 58, 216-234.

Caldwell, B.A., 2005. Enzyme activities as a component of soil biodiversity: a review. Pedobiologia 49, 637-644.

Cenini, V.L., Fornara, D.A., McMullan, G., Ternan, N., Lajtha, K., Crawley, M.J., 2015. Chronic nitrogen fertilization and carbon sequestration in grassland soils: evidence of a microbial enzyme link. Biogeochemistry 126, 301-313.

Chróst, R.J., 1991. Environmental control of the synthesis and activity of aquatic microbial ectoenzymes. In: Chróst, R.J. (Ed.), Microbial Enzymes in Aquatic Environments. Springer-Verlag, New York, pp. 25-59.

Cotrufo, M.F., Wallenstein, M.D., Boot, C.M., Denef, K., Paul, E., 2013. The Microbial Efficiency-Matrix Stabilization (MEMS) framework integrates plant litter decomposition with soil organic matter stabilization: do labile plant inputs form stable soil organic matter? Global Change Biology 19, 988-995.

Edwards, G.R., Crawley, M.J., 1999. Herbivores, seed banks and seedling recruitment in mesic grassland. Journal of Ecology 87, 423-435.

Fornara, D.A., Steinbeiss, S., McNamara, N.P., Gleixner, G., Oakley, S., Poulton, P.R., Macdonald, A.J., Bardgett, R.D., 2011. Increases in soil organic carbon sequestration can reduce the global warming potential of long-term liming to permanent grassland. Global Change Biology 17 (5), 1925-1934.

German, D.P., Weintraub, M.N., Grandy, A.S., Lauber, C.L., Rinkes, Z.L., Allison, S.D., 2011. Optimization of hydrolytic and oxidative enzyme methods for ecosystem studies. Soil Biology and Biochemistry 43 (7), 1387-1397.

Grandy, A.S., Sinsabaugh, R.L., Neff, J.C., Stursova, M., Zak, D.R., 2008. Nitrogen deposition effects on soil organic matter chemistry are linked to variation in enzymes, ecosystems and size fractions. Biogeochemistry 91, 37-49.

Kandeler, E., Stemmer, M., Klimanek, E.-M., 1999. Response of soil microbial biomass, urease and xylanase within particle size fractions to long-term soil management. Soil Biology \& Biochemistry 31, 261-273.

Lal, R., 2004. Soil carbon sequestration impacts on global climate change and food security. Science 304 (5677), 1623-1627.

Lavorel, S., Grigulis, K., McIntyre, S., Williams, N.S.G., Garden, D., Dorrough, J., Berman, S., Quétier, F., Thébault, A., Bonis, A., 2007. Review: assessing functional diversity in the field - methodology matters! Functional Ecology 22, 134-147.

Lavorel, S., Grigulis, K., Lamarque, P., Colace, M.-P., Garden, D., Girel, J., Pellet, G., Douzet, R., 2011. Using plant functional traits to understand the landscape distribution of multiple ecosystem services. Journal of Ecology 99, 135-147.

Mergel, A., Timchenko, A., Kudeyarov, V., 1998. Role of plant root exudates in soil carbon and nitrogen transformation. In: Box Jr., James E. (Ed.), Root Demographics and Their Efficiencies in Sustainable Agriculture, Grasslands and Forest Ecosystems Developments in Plant and Soil Sciences, vol. 82. Springer Netherlands, pp. 43-54.

Peregrina, F., Pérez-Álvarez, E.P., García-Escudero, E., 2014. The short term influence of aboveground biomass cover crops on $C$ sequestration and $\beta$-glucosidase in a vineyard ground under semiarid conditions. Spanish Journal of Agricultural Research 12, 1000-1007.

Post, W.M., Kwon, K.C., 2000. Soil carbon sequestration and land-use change: processes and potential. Global Change Biology 6 (3), 317-327.

Quétier, F., Lavorel, S., Thuiller, W., Davies, I., 2007. Plant-trait-based modeling assessment of ecosystem-service sensivity to land-use change. Ecological Applications 17, 2377-2386.

Robson, T.M., Lavorel, S., Clément, J.-C., Le Roux, X., 2007. Neglect of mowing and manuring leads to slower nitrogen cycling in subalpine grasslands. Soil Biology and Biochemistry 39, 930-941.

Saiya-Cork, K.R., Sinsabaugh, R.L., Zak, D.R., 2002. The effects of long term nitrogen deposition on extracellular enzyme activity in an Acer saccharum forest soil. Soil Biology \& Biochemistry 34 (9), 1309-1315.

Shaw, A.N., DeForest, J.L., 2013. The cycling of readily available phosphorus in response to elevated phosphate in acidic temperate deciduous forests. Applied Soil Ecology 63, 88-93.

Sinsabaugh, R.L., Follstad Shah, J.J., 2011. Ecoenzymatic stoichiometry of recalcitrant organic matter decomposition: the growth rate hypothesis in reverse. Biogeochemistry $102,31-43$.

Sinsabaugh, R.L., Antibus, R.K., Linkins, A.E., McClaugherty, C.A., Rayburn, L., Repert, D., Weiland, T., 1993. Wood decomposition: nitrogen and phosphorus dynamics in relation to extracellular enzyme activity. Ecology 74 (5), 1586-1593.

Sinsabaugh, R.L., Gallo, M.E., Lauber, C., Waldrop, M.P., Zak, D.R., 2005. Extracellular enzyme activities and soil organic matter dynamics for northern hardwood forests receiving simulated nitrogen deposition. Biogeochemistry 75, 201-215. Sinsabaugh, R.L., Lauber, C.L., Weintraub, M.N., Ahmed, B., Allison, S.D., 
Crenshaw, C.L., Contosta, A.R., Cusack, D., Frey, S., Gallo, M.E., Gartner, T.B., Hobbie, S.E., Holland, K., Keeler, B.L., Powers, J.S., Stursova, M., TakacsVesbach, C., Waldrop, M., Wallenstein, M., Zak, D.R., Zeglin, L.H., 2008. Stoichiometry of soil enzyme activity at global scale. Ecology Letters 11, 1252-1264. Sinsabaugh, R.L., Hill, B.H., Follstad Shah, J.J., 2009. Ecoenzymatic stoichiometry of microbial organic nutrient acquisition in soil and sediment. Nature 462 (7274), 795-798.

Sollins, P., Homann, P., Caldwell, B.A., 1996. Stabilization and destabilization of soil organic matter: mechanisms and controls. Geoderma 74, 65-105.

Stott, D.E., Andrews, S.S., Liebig, M.A., Wienhold, B.J., Karlen, D.L., 2010. Evaluation of $\beta$-Glucosidase activity as a soil quality indicator for the soil management assessment framework. Soil Science Society American Journal 74, 107-119.

Stursová, M., Baldrian, P., 2011. Effects of soil properties and management on the activity of soil organic matter transforming enzymes and the quantification of soil-bound and free activity. Plant and Soil 338, 99-110.

Stursová, M., Crenshaw, C.L., Sinsabaugh, R.L., 2006. Microbial responses to longterm N deposition in a semiarid grassland. Microbial Ecology 55, 90-98.

Sweeney, J., 1997. Ireland. In: Wheeler, D., Mayes, J. (Eds.), Regional Climates of the
British Isles. Routledge, London, pp. 254-275.

Trasar-Cepeda, C., Leirós, M.C., Gil-Sotres, F., 2008. Hydrolytic enzyme activities in agricultural and forest soils. Some implications for their use as indicators of soil quality. Soil Biology \& Biochemistry 40, 2146-2155.

Turner, B.L., 2010. Variation in pH optima of hydrolytic enzyme activities in tropical rain forest soils. Applied and Environmental Microbiology 76, 6485-6493.

Wallenius, K., Rita, H., Mikkonen, A., Lappi, K., Lindström, K., Hartikainen, H. Raateland, A., Niemi, R.M., 2011. Effects of land use on the level, variation and spatial structure of soil enzyme activities and bacterial communities. Soil Biology \& Biochemistry 43, 1464-1473.

Wallenstein, M., Allison, S.D., Ernakovich, J., Steinweg, J.M., Sinsabaugh, R.L., 2011 Controls on the temperature sensivity of soil enzymes: a key driver of in situ enzyme activity rates. In: Shukla, G., Varma, A. (Eds.), Soil Enzymology. Springer-Verlag, Berlin, Germany, pp. 245-258.

Welbaum, G.E., Sturz, A.V., Dong, Z., Nowak, J., 2004. Managing soil microorganisms to improve productivity of agro-ecosystems. Critical Reviews in Plant Sciences 23, 175-193. 